\title{
ATTITUDES OF THE INVOLVED SUBJECTS TO THE ISSUE OF BIODIVERSITY CONSERVATION IN THE PROTECTED AREA OF THE MALÉ KARPATY MTS (RESULTS OF PERSONAL INTERVIEWS)
}

\author{
MILENA MOYZEOVÁ, ZITA IZAKOVIČOVÁ
}

Institute of Landscape Ecology of SAS, Štefánikova 3, 81499 Bratislava, Slovak Republic; e-mail: milena.moyzeova@ savba.sk, zita.izakovicova@savba.sk

\begin{abstract}
Moyzeová M., Izakovičová Z.: Attitudes of the involved subjects to the issue of biodiversity conservation in the Protected Area of the Malé Karpaty Mts (Results of personal interviews). Ekológia (Bratislava), Vol. 35, No. 4, p. 392-400, 2016.

The aim of this paper is to evaluate the biodiversity from the stakeholders' point of view as well as to identify the conflicts of interests and the ensuing problems between hunting and the development of other socio-economic activities in the central part of Protected Area of the Little Carpathians. The specified conflicts of interests between hunters, conservationists and farmers are followed by measures that may contribute to increase the biodiversity in this model territory.
\end{abstract}

Key words: landscape protection, biodiversity, stakeholders.

\section{Introduction and the aim of the study}

Currently, the protection of landscape biodiversity in the Slovak Republic is subject to the Act of the Slovak National Council No. 543/2002 about landscape and nature conservation in wording of later issued provisions. This Act introduced an all-encompassing conception of nature protection founded in the territorial system of ecological stability and classification of the entire Slovak territory into five degrees of protection. The first degree is the most general one and relates to the whole territory of the SR. The second to fifth degrees apply to the individual types of protected areas. The extensive network of protected areas that exist in the country spreads over almost $23.15 \%$ of its total area (Miklós et al., 2006).

The Institute of Landscape Ecology participates in several national and international projects focused on nature protection, that of natural and cultural/historical resources and biodiversity. One of them was the ALTER-NET Project, part of the EU 6th Framework Programme. The principal aim of this project has been the integration of scientific capacities in biodiversity protection on the European level and creation of a network for the long-term European investigation of biodiversity and ecosystems. Part of its aim was also the analysis of developments in landscape and the change in biodiversity, as well as harmonisation of biodiversity protection with land use 
with active participation of stakeholders. Land owners, administrators and users took part in the assessment of biodiversity changes as their attitudes and opinion may contribute to biodiversity protection and enforcement of sustainable land use.

The aim of the present study is to identify conflicts

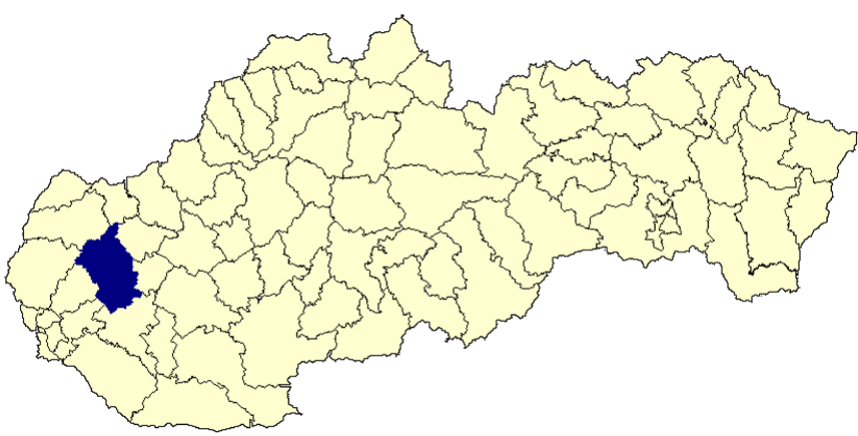

Fig. 1. Location of the model area. of interest and the ensuing problems between hunting activities and the development of other socio-economic activities in the central part of the Protected Area of the Malé Karpaty Mts part of which extends to the district of Trnava (Fig. 1). Subjects that influence biodiversity of the territory include forest managers, farmers and also conservationists.

\section{Basic characteristics of the model territory}

The Male Karpaty Mts are one of the 14 large protected areas in the territory of Slovakia in the category of Protected Landscape Area (PLA). It was established by the Decree of the Ministry of Culture of the Slovak Socialist Republic No. 64 in 1976. This landscape area is the only one protecting a large wine-growing region, and it is part of the Western Carpathians, Fatra-Tatra region. It is located in the western part of the country and consists of the mountain ranges Karpaty, Pezinské Karpaty, Brezovské Karpaty and Čachtické Karpaty. The core mountain range has been subject to a specific development of the crystalline complex containing granitoid rocks, limestone, schist, phyllite, amphibolites and other rocks. The relief is that of upland and highland. The central part of the Malé Karpaty Mts is rich in karstic phenomena. The major part of the PLA consists of forest ecosystems in edges transiting into agricultural land pool. The geosystem of the carbonate upland is covered by Rendzinas or Pararendzinas with calciphile oak-beech woods. Regarding biodiversity, this is an important area with abundant occurrence of many protected plant and animal species such as spring adonis (Adonis vernalis), bunchgrass Chrysopogon gryllus (L.), greater pasque flower (Pulsatilla grandis) and dianthus (Dianthus praecox subsp. lumnitzeri) and also species with unique occurrence in this area such as horse tongue lily Ruscus hypoglossum (L.), buckthorn (Rhamnus saxatilis) and the like. Important bird species in the territory of the Malé Karpaty Mts are represented by, for instance, common rock thrush (Monticola saxatilis), northern wheatear (Oenanthe oenanthe), saker falcon (Falco cherrug), black stork (Ciconia nigra), European honey buzzard (Pernis apivorus), snake eagle (Circaetus gallicus), Eurasian eagle-owl (Bubo bubo), long-eared owl (Asio otus), European nightjar (Caprimulgus europaeus) and so on. The prevailing part of the PLA is subject to the second degree of protection. The PLA contains 8 National Nature Reserves, 23 Nature Reserves, 2 National Nature Phenomena 
and 12 Nature Phenomena, under the top, the fifth degree, of protection. They are, for instance, Čachtický hradný vrch, Pohanská, Hajdúky, Dolina Hlboče, Záruby, Kršlenica, Devínska Kobyla, Roštun, caves Driny, Deravá skala, Čachtická, Tmavá skala, Plavecká and Velká Pec, as well as Vyvieračka pod Bacharkou, Bolehlav, Buková, Čerenec, Čierna skala and the like (Izakovičová et al., 2002 adapted).

The model territory chosen with regard to the assessment of hunting activity is the PLA of the Malé Karpaty Mts stretching from the village Dolné Orešany along the ridge of the mountain range as far as the village Dobrá Voda. The territory also includes the buffer zone in order to cover a part of the hunting ground. The Malé Karpaty Mts hunting ground consists of two parts, the field and the forest sections. The authors concentrated on the hunting grounds of Solírov-Dolné Orešany, Majdán, Záruby, Nová Skalka, Kamenec-Buková, Zavadil-Raková, Prekážka-Cerov Majer, Planinka-Dechtice, Suchánka-Dobrá Voda, and Skalky-Dobrá Voda. The buffer zone contains the edges of the Malé Karpaty Mts.: Lúčky-Dlhá, Dolné Orešany, Podhora-Horné Orešany, Záruby-Smolenice, Nádaši-Trstín, Trihalier-Krupá, Brdo-Naháč and Borinka-Dechtice. These grounds are mixtures of forest and arable land. The boundaries of hunting grounds trace those of the cadastre and in places they spread to the neighbouring districts. The area of interest belongs to the region of roe game breeding, which is denoted as SII/2 and SII/3. Apart from the roe, fallow and red deer are also the species bred here. The small game breeder region is denoted as N5/1, N5/2 and N6 (Landscape Atlas, 2002) with species such as pheasant, partridge, duck and also roe game.

Forest authorities in this territory administer about 39,000 ha of forest, where 30,000 ha is the state property and 9,000 ha are privately owned. The state administration, that is, forest offices determine the numbers of game for individual hunting grounds that can be bred per 1,000 ha taking into account the size of the area and natural conditions.

\section{Theoretical and methodological base}

Conflicts of interests arise in spatial overlapping of individual territorial systems in landscape and may be the source of ecological and environmental problems. Problems are due to the spatial clash between the ecologically valuable elements of landscape structure considered threatened phenomena and the stress factors of territorial system that assume the role of threatening phenomena (Ružička, Miklós, 1982; Miklós, 1985; Izakovičová, Moyzeová, 2000, 2008).

The centre of evaluation of socio-economic phenomena in terms of landscape ecological planning lies in the evaluation of collisions of interests and ecological problems resulting from these collisions. The evaluation philosophy is based on the interpretation of socio-economic phenomena from the landscape ecology point of view. According to this point of view, the socio-economic phenomena can be divided into

- Endangered phenomena.

- $\quad$ Endangering phenomena.

Endangered phenomena are positive elements from the landscape ecology point of view, because they ensure landscape protection and stability, as well as natural resources exploiting in a rational manner. These are socio-economic phenomena representing especially interests of protection of nature and natural resources. In this group, there are legislative measures for the protection of nature, natural resources, health and recreation resources - declared as protected natural 
landscapes, areas of different levels of protection, protected zones and so on - as well as other interests on the protection of nature, natural resources, health and recreation resources, that means other ecologically valuable areas, that are still undeclared legislatively.

Endangering phenomena are negative landscape phenomena endangering its stability and biodiversity, as well as its particular natural resources. These are especially phenomena representing interests of production branches development. In this group, there are zones of negative influence of anthropogenic buildings, as well as negative accompanying phenomena of production pollution - air pollution, water and soil contamination, protected zones of hygienic and technical character and so on.

Owing to a collision of endangered and endangering phenomena in an area, ecological problems have arisen. According to the character of the mutual combination of collision phenomena, ecological problems (Fig. 2, Table 1, and Legend) can be divided into three basic groups:

A. Environmental problems of endangering of landscape spatial stability.

B. Environmental problems of endangering of natural resources.

C. Environmental problems of environment endangering.

Regarding the nature of territory, focus was on the assessment of conflict of interests between

- Hunting and nature conservation.

- Hunting and forest management.

- Hunting and farming.

The methodology consisted of the following basic steps:

1. Analysis of available literature involved with the topic.

2. Sociological survey carried out via personal interviews with the representatives of selected

$\mathrm{T}$ a b l e 1. Conflicts of interest in the Trnava region.

\begin{tabular}{|c|c|c|c|c|c|c|c|c|c|c|c|c|c|c|}
\hline & \begin{tabular}{|l|}
$\begin{array}{c}\text { Damagag of } \\
\text { vegetition }\end{array}$ \\
\end{tabular} & $\begin{array}{c}\text { Minerats } \\
\text { mining }\end{array}$ & Wood cututing & 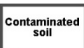 & 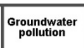 & 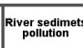 & Arable soil & \begin{tabular}{|l|l|l} 
Air polutution \\
\end{tabular} & 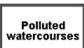 & $\begin{array}{l}\text { Intensive } \\
\text { trantaric }\end{array}$ & Erosion & \multicolumn{3}{|c|}{ 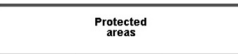 } \\
\hline 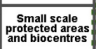 & & & & 12 & & & & & & N. & & industy yerea & 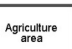 & Waste dumps \\
\hline 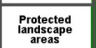 & & 57 & 0 & II & & & $\square$ & & & & & & & \\
\hline $\begin{array}{l}\text { Suppocial } \\
\text { purtsoss }\end{array}$ & & & & 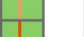 & & & & & & 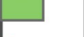 & & & & \\
\hline Blocorridors & & & & 你 & 装 & 272 & 31, & & & $x / x / x$ & & & & \\
\hline 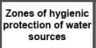 & & $E$ & & . & 7 & $\because A$ & . & & & $\nabla$ & & & & \\
\hline 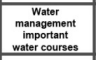 & & & & & & & & & & & & & & \\
\hline 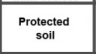 & & 57 & & D & 7 & $\triangle 1$ & & $\ldots$ & & $\nabla$ & 3 & & & \\
\hline \begin{tabular}{|l|} 
Resitential \\
areas
\end{tabular} & & & & & 1 & & & . & & $\nabla$ & & $\theta$ & $Q$ & $Q$ \\
\hline \begin{tabular}{|c|} 
Garcens and \\
orthardas
\end{tabular} & & & & T & 8 & & & $\ldots$ & & $\checkmark$ & & & & \\
\hline Vineyards & & & & 1 & & $\because$ & & 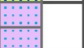 & & & $s$ & & & \\
\hline \begin{tabular}{|c|} 
Recreational \\
areas
\end{tabular} & & & & & & & & & & & & $Q$ & $Q$ & $Q$ \\
\hline
\end{tabular}

Notes: 1 - Small-scale protected area; 2 - protected landscape area Malé Karpaty Mts; 3 - purpose forests; 4 - other forests and non-forest woody vegetation; 5 - protected soil; 6 - other types of soil; 7 - permanent grassy vegetation; 8 - vineyards; 9 - gardens and orchards; 10 - watercourses and all surface water; 11 - industrial areas; 12 - waste dump; 13 - agricultural areas; 14 - residential areas; 15 - recreational areas. 
branches/sectors.

3. Evaluation of replies to personal interviews and identification of conflicts of interest.

4. Suggested solutions to specified problems in terms of biodiversity.

\section{Results of the assessment}

1. The analysis of available literature dealing with the territory of the Malé Karpaty Mts showed that the solutions to the conflict of interests between game hunting and keeping and the development of other socio-economic activities were not given much attention. The territory has been subject to many studies, particularly monographs that deal with the assessment of natural conditions of the territory of interest. About 200 titles focus on the research of biota, geological conditions and geomorphological conditions. Topics such as for-

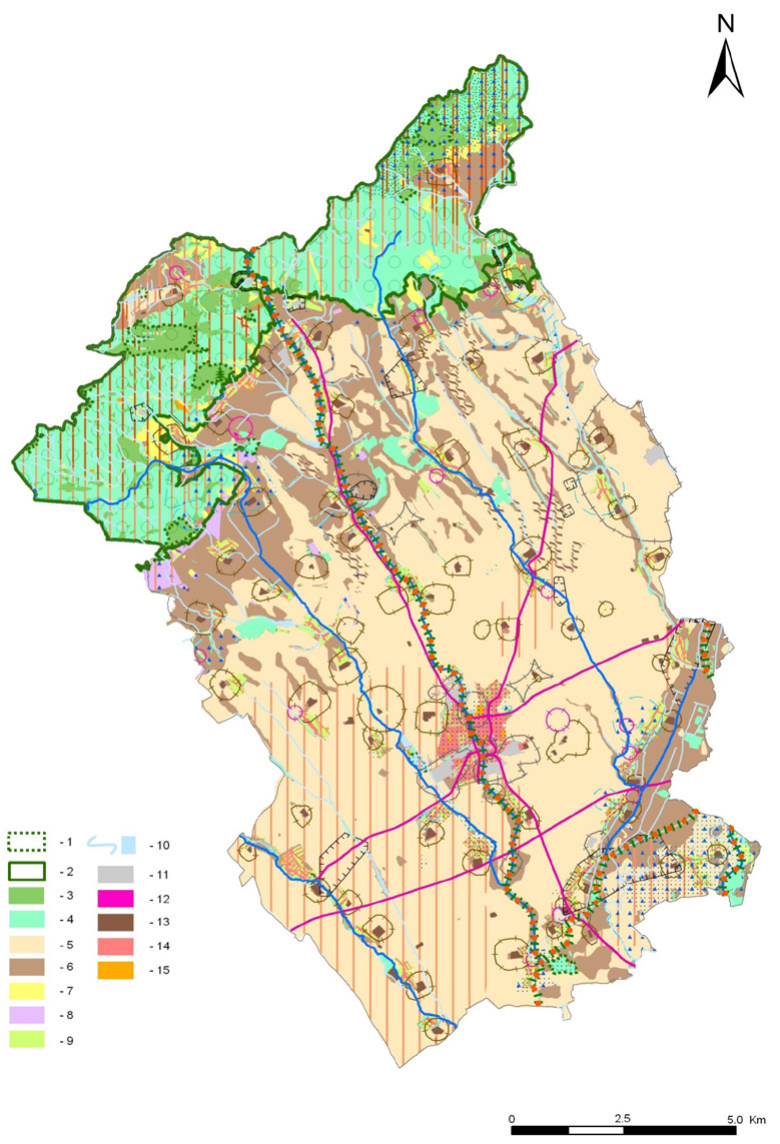

Fig. 2. An example of evaluations of the ecological problems in the Trnava region. est ecosystems, beech woods of the Malé Karpaty Mts, diptera, reptiles, dragonflies, bats, fauna of ephemeroptera, molluscs, territorial diversity, pedology, phytodiversity, recreation and wine growing are also dealt with.

2. Adult respondents were addressed with the aim to initiate short- and long-term partnership for discussion. The group of communicators meant to acquire information about diversity consisted of the Hunting Association representatives (Chairman of the district hunting union in Trnava, member of the local unit of Hunting Association), representatives of forest management (director of the Forest Works, head of the department of forest management at the district office of Trnava), representatives of nature conservation (director administrator of the PLA of the Malé Karpaty Mts), representatives of the Landscape Association 21 and representatives of farmers (AGROPO, the agricultural entity active in the territory in question). Apart from 
personal characteristics such as the age, sex and formation, the answers to the following questions have been analysed:

- Are there any issues related to nature and biodiversity conservation (for instance, deforestation, loss of nesting conditions, diminishment of birds depending on these conditions and the like) that worry you?

- Did you notice similar problems in the past (for instance, development of agriculture, melioration, removal of game refuges and field roads with linear vegetation, large-block husbandry, clear cutting, extraction of minerals, intensive recreation, etc.)?

- Do you think it is possible to quantify these changes in some way?

- What is beneficial for the territory in question and what should be done to improve the present situation in biodiversity conservation?

- Do you know of any examples from abroad how to increase biodiversity?

3. Several entities are active in the territory of the Malé Karpaty Mts influencing the biodiversity in this area. Apart from hunters active in the Malé Karpaty Mts. Roe Deer Hunting Region, there are also conservationists (the area of PLA of the Malé Karpaty Mts is subordinate to the administration seated in Modra, foresters of Smolenice, farmers and wine-growers). Analysis of replies made it possible to identify the main conflicts of interests and also the ways of elimination of specified problems.

\section{Identification of conflicts of interests}

Three groups of conflicts of interests were identified in the territory:

\section{A/ Conflicts of interests between hunters and conservationists}

As perceived by hunters:

- Conservationists curtail hunters because of species protection.

If conservationists designate preservation of some predator, its kill is banned for the whole year in spite of the damage it may cause. Hunters believe that the man-protected species are overpreserved. Amongst them are, for instance, ravens, cormorants and herons.

- Conservationists also curtail hunters in terms of location of small protected areas.

It is prohibited to execute rights of hunting in the location of small protected areas. No hunting and care for the game including supplementing feeding and construction of hunting structures are allowed.

...In this country almost each hunting ground contains some protected natural phenomenon, occurrence of a protected plant or animal. Driny-Smolenice, Záruby are fairly big localities where there is a ban on hunting, feeding and hunting facilities...

As perceived by conservationists:

- The PLA contains the mouflon breeding area.

It is one of the most serious conflicts of interests, as these territories contain protected areas of the European importance and their principal mission is to secure protection of an acceptable state of biotopes.

- Nitrification of top associations ensuing from the high game concentration in top parts of the territory. 
Nature reserves are also located in these parts. Grassland, scarce human presence and tranquillity represent favourable conditions for the beasts that like to dwell here.

- Transformation of the ecological nature of some biotopes; nitrophilic species invade the places where there is high concentration of game, the territory becomes ruderal like after cattle folding.

- Game feeding.

Hunters haul vegetable, fruit and cereal wastes to hunting grounds where they ferment and decay. This practice may introduce numerous other than original and invasive plants species in the area. There is also the danger of propagation of diseases.

...In reserves under the strictest protection there is a ban of hunting rights that is, hunting, and building of hunting facilities such as salt-licks, feeders, and high stands. For instance, in Hlboča near Smolenice feeding increases game concentration and the damage done by the game is also big in this locality...

- Unlawful killing of predators.

Bird predators that nest in higher position of the Malé Karpaty Mts hunt in foothills and may become victims to illegal shooting.

- Game preserves.

Game preserves are fenced and represent barriers for migration of other wild animal species in the Malé Karpaty Mts.

- Reduced landscape aesthetics.

It is a marginal problem concerning construction of hunting facilities applying poor-quality materials (sheet metal, plastics and the like).

\section{B/ Conflicts of interests between hunters and farmers.}

- Changed species composition of grown crops.

Agricultural entities often grow monocultures on large areas. Beet, which maintained populations of the hare and the grey partridge, has almost disappeared from the fields. Numbers of hare depending on varied food are endangered.

- Inoperative melioration.

Melioration used to uphold moisture in landscape. Today, hunters are compelled to dig wells for the game as many irrigation facilities are now inoperative.

...Composition of seed and abundance of water are important factors, which influence the capacity of reproduction of, for instance, the hare. Numbers of hare are constantly decreasing in these parts of the hunting ground...

- Chemicalisation of agriculture.

Sunflower and corn are sprayed with herbicides and game is slowly disappearing. Numbers of hares here are below the normal status.

- Destruction of game refuges.

Use of big mechanisms in agriculture results in destruction of the last remnants of greenery in the cadastre.

...Austria is an example to follow. Hunting in this country is based on year-round game feeding, planting of greenery and game refuges which contribute to high numbers of game... 
- Nibbling at the wine grape.

Large vineyards in the boundary zone of the Malé Karpaty Mts foothills are exposed to nibbling of wine grape. vine...

... For instance, vineyards at Dolné Orešany are not fenced. Beasts gather here and damage the

\section{$\mathrm{C} /$ Conflicts of interests between hunters and foresters}

- Obstructed natural restoration of forest.

Oak and beech woods in the Malé Karpaty Mts are of good quality. Games, especially mouflons, damage the tops of stands hindering their natural rejuvenation. This problem has been especially notable in recent years.

...If a beech nut falls off the tree, mufloun eats it. If he does not eat it, and the nut develops into a small beech, he will eat that. He bites off its terminal and the tree would stop growing remaining on the same level even ten years...

- High cost of forest cultures ensuing from high numbers of game, especially mouflons.

Numbers of mouflons are several folds higher than the carrying capacity of the environment. Fed game also needs the tannin and is able to annihilate an entire young growth causing high cost of cultural wood species to foresters.

In general, cooperation exists between conservationists, foresters and hunters in this territory. If problems pop up, nature and landscape conservation is always a priority, because of the existence of the PLA of the Malé Karpaty Mts.

...Regarding this issue, hunting, forestry, agriculture and the environmental protection must find a common language. Compromise is always possible. Let us meet halfway...

Measures proposed in order to find solutions to the specified problems:

- Regulation of numbers of some predator species.

Sole protection of predators leads to their overpopulation on the one side and distinctly reduced numbers of not protected species on the other. It is necessary to introduce efficient regulating mechanisms in order to preserve biodiversity of all species.

- Instead of working all land, part of it should be idle. low.

In general, it seems that $10-20 \%$ of agriculturally exploited land should be allowed to lie fal-

- Expansion of greenery in agriculturally intensively used landscape.

Twenty-one game refuges are distributed all over the shooting ground, providing shelter and resting place to the game should help.

- Changed crop rotation.

It is advisable to alternate crops with the aim to provide a wider choice of food for the game.

- New legislation.

A new law, new regionalisation and quality assessment of shooting ground should bring some optimal changes in future. Important for the conservationists is the task of securing and supporting the original species composition typical for the Malé Karpaty Mts territory and to strive for a consistent protection of the biotopes significant in the European scale. Activities of hunters should be focused on the attention to animal species that once existed here and disappeared, for instance, wild cat or hazel grouse. 
- Monitoring and regulation of game numbers.

Monitoring and regulation of game numbers matching the carrying capacity of the given territory may help address the problems of damage to forest ecosystems.

\section{Conclusion}

Evaluation of the socioeconomic phenomena, collisions of interests and ecological problems has been applied also in terms of many ecology studies: Ecology Generel of the Slovak Republic, in ecological evaluation of Central Slovakia, ecological evaluation of agricultural area in Trnava and Voderady, evaluation of ecologically charged areas revitalisation in Jelšava-Lubeník and HnúštaHačava, scenarios and stakeholder perceptions in the Poloniny National Park and so on. Problems in model territory are many; however, it is the attitude of all stakeholders in the issue of biodiversity conservation in this territory that is important. Not only the representatives of the State Nature but also hunters, foresters and farmers are aware of the importance and meaning of biodiversity preservation and wish to carry out their activities in a way that contributes to preservation of and increase in biodiversity.

\section{Summary}

The evaluation of the conflicts of interests is concentrated on a study of environmental problems resulting from the inappropriate land-use structure. The aim of this approach is to define the types and relevance of environmental problems and their localisation in the territory and to elaborate proposals for the problem elimination. The paper is an example of identification of interests resulting from conflicts between the realisation of hunter activities and the development of other socio-economic activities in the protected area of the Malé Karpaty Mts.

\section{Acknowledgements}

This work was supported in part by Grant agency for science (grant No. 2/0066/2015): Green infrastructure of Slovakia.

\section{References}

Act No. 543/2002 About nature and landscape protection in wording of later issued provisions (in Slovak).

Act No. 274/2009 Hunting Act (in Slovak).

Atlas krajiny SR (2002). Bratislava: MŽP SR, Banská Bystrica: SAŽP.

Izakovičová, Z. \& Moyzeová M. (2000). Evaluation of environmental problems arising from collisions of interests in the region of the Tatras. Ekológia (Bratislava), 19(Suppl. 2), 168-176.

Izakovičová, Z. et al. (2002). Landscape-ecological plan of district Trnava (in Slovak). Bratislava: ÚKE SAV.

Izakovičová, Z. \& Moyzeová M. (2008). Environmental evaluation of the impact of human activities in the landscape. Gospodarka Surowcami Mineralnymi, 24(2/2), 154-158.

Miklós, L. (1985). Conflicts of interests in landscape (in Slovak). Životné Prostredie, 19(4), 179-184.

Miklós, L., Izakovičová, Z. et al. (2006). Atlas of representative geo-ecosystems of Slovakia. (in Slovak). Bratislava: ÚKE SAV, MŠ SR.

Ružička, M., Miklós, L., 1982: Landscape-ecological planning (LANDEP) in the process of territorial planning. Ekológia (ČSSR), 1(3), 297-312. 